\title{
Trans Fatty Acids in European Margarines
}

\section{Citation}

Michels, Karin, and Frank Sacks. 1995. "Trans Fatty Acids in European Margarines." New

England Journal of Medicine 332 (8) (February 23): 541-542. doi:10.1056/nejm199502233320817.

\section{Published Version}

doi:10.1056/NEJM199502233320817

\section{Permanent link}

http://nrs.harvard.edu/urn-3:HUL.InstRepos:30203965

\section{Terms of Use}

This article was downloaded from Harvard University's DASH repository, and is made available under the terms and conditions applicable to Other Posted Material, as set forth at http:// nrs.harvard.edu/urn-3:HUL.InstRepos:dash.current.terms-of-use\#LAA

\section{Share Your Story}

The Harvard community has made this article openly available.

Please share how this access benefits you. Submit a story.

Accessibility 


\section{CORRESPONDENCE}

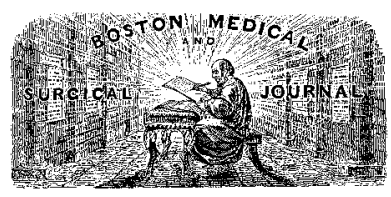

\section{CORONARY-STENT PLACEMENT COMPARED WITH BALLOON ANGIOPLASTY}

To the Editor: The Benestent ${ }^{1}$ and Stent Restenosis (STRESS) ${ }^{2}$ studies (Aug. 25 issue) raise important questions about strategies for coronary-stent placement. Should coronary stents be considered for all patients with new focal lesions in large coronary arteries that have a high likelihood of dissection, ${ }^{3}$ or should they be used only on a conditional basis if balloon angioplasty does not achieve the desired degree of dilation?

Although the randomized studies ${ }^{1,2}$ showed that coronarystent placement reduced the rate of clinical restenosis, the only component of the composite end point that was favorably affected was the need for a second intervention involving the original coronary lesion. Coronary-stent placement did not reduce the risk of death or major complications such as myocardial infarction, because stent thrombosis occurred in 3 to 4 percent of patients up to two weeks after treatment and was usually associated with death or myocardial infarction. Other drawbacks of coronary-stent placement included major hemorrhage in 7 to 14 percent of patients ${ }^{1,2}$ and rates of angiographic restenosis ${ }^{1,2}$ that fell short of the values needed to produce a cost savings. ${ }^{4}$

An intraprocedural strategy of conditional stent placement for patients with stenoses of more than 25 to 30 percent after balloon angioplasty should be considered. Such a strategy is reasonable because dilation with balloon angioplasty is re- quired in all patients before they undergo coronary-stent placement, and the rate of angiographic restenosis depends on the luminal diameter at the time of the procedure, not on the dilating procedure itself., ${ }^{2,5}$ If dilation with balloon angioplasty can achieve a "stent-like" result, the benefits of a large postprocedural luminal diameter should be conferred without the need for coronary-stent placement. The safety of the conditional approach is suggested by the results of the Benestent study, in which no complications occurred in patients undergoing elective bypass surgery who underwent bailout coronary-stent placement after failed balloon angioplasty. ${ }^{1}$

Boston, MA 02115

John A. BitTL, M.D.

1. Serruys PW, de Jaegere P, Kiemeneij F, et al. A comparison of balloonexpandable-stent implantation with balloon angioplasty in patients with coronary artery disease. N Engl J Med 1994;331:489-95.

2. Fischman DL, Leon MB, Baim DS, et al. A randomized comparison of coronary-stent placement and balloon angioplasty in the treatment of coronary artery disease. N Engl J Med 1994;331:496-501.

3. Topol EJ. Caveats about elective coronary stenting. N Engl J Med 1994;331: 539-41.

4. Cohen DJ, Breall JA, Ho KK, et al. Evaluating the potential cost-effectiveness of stenting as a treatment for symptomatic single-vessel coronary disease: use of a decision-analytic model. Circulation 1994;89:1859-74.

5. Kuntz RE, Gibson CM, Nobuyoshi M, Baim DS. Generalized model of restenosis after conventional balloon angioplasty, stenting and directional atherectomy. J Am Coll Cardiol 1993;21:15-25.

To the Editor: The two recently published studies comparing the implantation of a Palmaz-Schatz stent and balloon angioplasty are the first major studies to demonstrate a favorable effect on restenosis. ${ }^{1,2}$ Although the authors correctly qualify the generalizability of the results, they do not address two important issues.

First, as the accompanying editorial suggests,${ }^{3}$ information on the timing of restenosis after stenting is incomplete as compared with what is known about events after balloon angioplasty. The serial angiographic study of Nobuyoshi et al. ${ }^{4}$ established that only 6 percent of cases of restenosis after bal-

\section{Instructions for Letters to the Editor}

Letters to the Editor are considered for publication (subject to editing and abridgment), provided they are submitted in duplicate, are typewritten and triple-spaced, and do not exceed 400 words of text, a maximum of five references, and one figure or table. Letters should have no more than three authors, and all should sign the letter. Please include a word count, your telephone number, and your fax number (if available).

Letters should not duplicate similar material being submitted or published elsewhere, and they should not contain abbreviations. Financial associations or other possible conflicts of interest should always be disclosed. Submission of a letter constitutes permission for the Massachusetts Medical Society, its licensees, and its assignees to use it in the Journal's various editions (print, data base, and optical disk), in anthologies, revisions, and any other form or medium.

Letters referring to a recent Journal article must be received within four weeks of the article's publication. To expedite receipt of such letters, we encourage authors outside the United States to communicate by fax (617-739-9864 or 617-734-4457).

The Journal accepts letters to the Editor by electronic mail. The Internet address is letters@edit.nejm.org.

We are unable to provide prepublication proofs, and unpublished material will not be returned to authors unless a stamped, self-addressed envelope is enclosed. Receipt of letters is not acknowledged, but correspondents will be notified when a decision is made. 
loon angioplasty occur after six months. The trials of stenting ended their follow-up at seven months ${ }^{1}$ and six months ${ }^{2}$ and would have missed a delayed process of renarrowing after stent placement if such a process indeed occurred.

Second, neither study was designed to examine the issue of the care of patients in whom restenosis develops after the index procedure. It has been shown that second balloon angioplasties for restenotic lesions after angioplasty are exceptionally safe, with a lower risk than first-time procedures and an acceptable rate of restenosis ( 31 percent). ${ }^{5}$ Early data, however, suggest that the management of restenotic lesions in a stent may be problematic, since the incidence of restenosis after balloon angioplasty of such lesions is possibly as high as 54 percent. $^{6}$

Until information based on longer follow-up is available from these two excellent studies, ${ }^{1,2}$ the use of elective stent implantation as a general approach to the treatment of new native coronary-artery lesions does not seem justified.

\section{Toronto,}

\section{ON M5G 2C4, Canada}

LEONARD Schwartz, M.D. Toronto Hospital

1. Serruys PW, de Jaegere P, Kiemeneij F, et al. A comparison of balloonexpandable-stent implantation with balloon angioplasty in patients with coronary artery disease. N Engl J Med 1994;331:489-95.

2. Fischman DL, Leon MB, Baim DS, et al. A randomized comparison of coronary-stent placement and balloon angioplasty in the treatment of coronary artery disease. N Engl J Med 1994;331:496-501.

3. Topol EJ. Caveats about elective coronary stenting. N Engl J Med 1994;331: 539-41.

4. Nobuyoshi M, Kimura T, Nosaka H, et al. Restenosis after successful percutaneous transluminal coronary angioplasty: serial angiographic follow-up of 229 patients. J Am Coll Cardiol 1988;12:616-23.

5. Black AJ, Anderson HV, Roubin GS, Powelson SW, Douglas JS Jr, King SB III. Repeat coronary angioplasty: correlates of a second restenosis. J Am Coll Cardiol 1988;11:714-8.

6. Baim DS, Levine MJ, Leon MB, Levine S, Ellis SG, Schatz RA. Management of restenosis within the Palmaz-Schatz coronary stent (the U.S. multicenter experience). Am J Cardiol 1993;71:364-6.

The authors reply:

To the Editor: By the time the results of large trials such as the Benestent and STRESS studies are published, their clinical implications are already to some extent obsolete, and interventional practice and the care of patients have evolved substantially. The reported limitations and drawbacks of coronary stenting as done in our study are fully appreciated and acknowledged by the Benestent investigators, as well as by Dr. Bittl.

In order to reduce the incidence of adverse events associated with elective stenting, Dr. Bittl proposes that stent placement should be performed only in selected patients - those in whom primary balloon angioplasty fails ${ }^{1,2}$ or does not result in an optimal residual luminal diameter., ${ }^{1,2}$ Such an intraprocedural strategy of conditional stenting is not without merit and was indeed used for patients in Benestent who were randomly assigned to the balloon-angioplasty group. In accordance with the recommendations of the reviewers and the editors of the Journal, a crossover to bailout stenting was not counted as a clinical event but, rather, was deemed to be an integral component of the balloon-angioplasty package. Thus, it may be considered that as reported, Benestent has already demonstrated that the primary strategy of elective stenting is superior to that of elective balloon angioplasty with the option of bailout stenting.

The specific residual stenosis (10 percent, 20 percent, 30 percent, or 35 percent of the diameter, or some other value) after primary balloon angioplasty at which conditional stenting should be considered would be difficult to determine in the context of a prospective trial with on-line quantitative coronary angiography. ${ }^{3}$ Dr. Bittl's proposal of relying on the achievement of a large luminal diameter by balloon angioplasty suggests that he does not believe that stenting works by preventing restenosis - an opinion to which we do not subscribe. ${ }^{4,5}$

Rather than withhold elective stent placement from patients undergoing angioplasty, the Benestent investigators are attempting to reduce the incidence of stent-related adverse events by incorporating a heparin coating on the stent and replacing the combination of anticoagulant drugs (heparin and coumadin) by a combination of platelet-antiaggregatory drugs (ticlopidine and aspirin) in Benestent II. In so doing, we anticipate that the drawbacks of prolonged hospitalization, hemorrhagic complications, and subacute stent occlusion will be eliminated, partially or completely, so that elective stenting of new coronary lesions will become an attractive and superior alternative to balloon angioplasty.

Dr. Schwartz's concern about the possible temporal discordance in the degree of luminal renarrowing after balloon angioplasty and after stenting can be dispelled. The results of the 1-year follow-up of the Benestent study demonstrate that the clinical benefit observed at 7 months is indeed preserved at 12 months, with 12 -month event rates of 32 percent and 23 percent for balloon angioplasty and stenting, respectively. As for the management of stent restenosis, on this question, too, we can reassure Dr. Schwartz that the rate of restenosis after angioplasty of restenotic stented lesions was 15 percent.

Patrick W. Serruys, M.D., Ph.D. 3000 DR Rotterdam, the Netherlands Erasmus University

\section{FOR THE Benestent InVESTIGATORS}

1. Keane D, Roubin G, Marco J, Fearnot N, Serruys PW. GRACE - Gianturco Roubin stent in Acute Closure Evaluation: substrate, challenges and design of a randomized trial of bailout therapy. J Interventional Cardiol 1994;7:333-9.

2. Serruys PW, Keane D. The bailout stent: is a friend in need always a friend indeed? Circulation 1993;88:2455-7.

3. Haase J, Keane D, DiMario C, Escaned J, Slager CJ, Serruys PW. How reliable are geometric coronary measurements? In vitro and in vivo validation of digital and cinefilm-based quantitative coronary analysis systems. In: Serruys PW, Foley DP, de Feyter PJ, eds. Quantitative coronary angiography in clinical practice. Vol. 145 of Developments in cardiovascular medicine. Dordrecht, the Netherlands: Kluwer Academic, 1994:27-49.

4. Foley D, Keane D, Serruys PW. Does the method of transluminal coronary revascularization influence restenosis? A comparison of balloon angioplasty, atherectomy and stents. Br J Clin Pract (in press).

5. Umans V, Keane D, Foley D, Boersma E, Melkert R, Serruys PW. Optimal use of directional coronary atherectomy is required to ensure long-term angiographic benefit: a study with matched procedural outcome after atherectomy and angioplasty. J Am Coll Cardiol (in press).

To the Editor: Dr. Bittl raises an important issue regarding the selection of patients for stent placement when he suggests that a conditional strategy of balloon angioplasty should be followed, with stent placement only if a desired lumen is not achieved after standard angioplasty. He suggests this strategy in view of the major limitations of stent placement, including thrombosis, bleeding, and vascular complications and the resultant longer hospital stay, as reported in the two recent studies in the Journal. ${ }^{1,2}$ Dr. Bittl's strategy is attractive and deserves further consideration, but in the STRESS trial, the plan of elective stent placement was intentionally to underdilate lesions before placing the stent, to avoid dissection of the intima. Although stents have been shown to resolve dissec- 
tions, placing a stent when the result of angioplasty is suboptimal has been associated with a higher incidence of stent thrombosis. Of the 14 patients randomly assigned to balloon angioplasty who underwent stent placement as a bailout procedure in the STRESS trial, thrombosis occurred in 3 (21 percent) and was associated with a major cardiac complication in each of these.

As we note in our article, the most important factor predictive of long-term angiographic patency in the STRESS trial was the luminal diameter achieved immediately after the procedure and not the particular method used. Stents reduced restenosis rates because they more often allowed the operator to achieve an optimal luminal diameter with less risk of dissection and recoil. The conditional strategy arouses the concern that attempts to achieve the optimal diameter with balloon angioplasty might result in dissection; subsequent stent placement would then be performed in a bailout situation, which might result in even higher complication rates.

We agree that the serious limitations of stenting require that patients be selected carefully. Stent placement is a rapidly evolving technique. Improvement in the techniques of deploying stents, with high-pressure balloon inflation as well as the coating of stents with antithrombotic materials, may reduce the incidence of stent thrombosis and the need for anticoagulation after the stent is deployed. Furthermore, the use of pneumatic vascular-compression devices has been associated with a marked reduction in bleeding and vascular complications. ${ }^{3}$ We believe that progress is being made to limit the serious drawbacks of thrombosis and bleeding. If these limitations are overcome, then stent placement will be even more attractive as a front-line procedure.

Dr. Schwartz asks whether stents may slow the temporal course of restenosis. Prospective serial follow-up data from our nonrandomized clinical trial demonstrated no deterioration in minimal luminal diameter between 6 and 12 months in 50 patients. ${ }^{4}$ However, we strongly agree with the need for further long-term follow-up evaluation.

DaVid L. Fischman, M.D. Michael P. Savage, M.D. Sheldon GoldBerg, M.D.

Philadelphia, PA 19107 Jefferson Medical College

1. Fischman DL, Leon MB, Baim DS, et al. A randomized comparison of coronary-stent placement and balloon angioplasty in the treatment of coronary artery disease. N Engl J Med 1994;331:496-501.

2. Serruys PW, de Jaegere P, Kiemeneij F, et al. A comparison of balloonexpandable-stent implantation with balloon angioplasty in patients with coronary artery disease. N Engl J Med 1994;331:489-95

3. Sridhar K, Porter D, Gupta B, et al. Reduction in peripheral vascular complications after coronary stenting by the use of a pneumatic vascular compression device. Circulation 1994;90(Part 2):I-621. abstract.

4. Savage MP, Fischman DL, Schatz RA, et al. Long-term angiographic and clinical outcome after implantation of a balloon-expandable stent in the native coronary circulation. J Am Coll Cardiol 1994;24:1207-12.

To the Editor: Bittl raises the possibility of conditional stenting as a strategy for the treatment of patients who have suboptimal results with balloon angioplasty. Rodriguez et al. ${ }^{1}$ have performed a small randomized trial of 66 patients who were found to have reduced luminal diameters at the time of a second angiographic procedure 24 hours after balloon angioplasty. Among the patients assigned to receive stents (with a Gianturco-Roubin design), the restenosis rate was 21 percent, as compared with 76 percent in the balloon-angioplasty-only group $(\mathrm{P}<0.001)$. These data provide preliminary support for the strategy that Bittl has proposed. However, patients who do not have satisfactory results with conventional dilation may be a special group of patients with coronaryartery lesions that are not fully responsive to stenting or other interventions (atherectomy, rotablation, or laser techniques) used for this purpose. This issue can only be resolved in a randomized, controlled trial, and it is one of several important future directions for research in the area of investigational coronary stenting.

\section{Cleveland, $\mathrm{OH} 44195$}

ERIC J. TOPOL, M.D. Gleveland Clinic Foundation

1. Rodriguez A, Santaera O, Larribau M, et al. Rational use of coronary stenting to prevent restenosis: a randomized study in lesions with early minimal luminal diameter loss after PTCA. J Am Coll Cardiol 1994;23:Suppl:118A. abstract.

\section{CLINICAL PROBLEM-SOLVING: THE APPROPRIATE DEGREE OF DIAGNOSTIC GERTAINTY?}

To the Editor: The case presented by Thibault (Nov. 3 issue $)^{1}$ illustrates a very common problem in clinical cardiopulmonary medicine. A simple objective test is widely available that would probably have averted the extensive and expensive workup.

The patient's peak flow should have been measured in the emergency room before and after treatment with the bronchodilator. I suspect the flow rate would have improved, as did his symptoms. Such evidence supports a diagnosis of reversible airway disease, or asthma. This patient could then have been instructed to measure and record his peak flow daily or when he had any episodes of chest tightness and shortness of breath. This record would have been helpful to his physicians in providing support for the diagnosis of periodic air-flow obstruction, reversible with inhaled bronchodilators. $^{2}$

\section{Charlottesville, VA 22902}

1. Thibault GE. The appropriate degree of diagnostic certainty. N Engl J Med 1994;331:1216-20.

2. National Asthma Education Program. Expert Panel report: guidelines for the diagnosis and management of asthma. Bethesda, Md.: Department of Health and Human Services, 1991. (NIH publication no. 91-3042.)

To the Editor: In a middle-aged, male exsmoker with exercise-induced dyspnea, one must pursue the possibility of proximal coronary disease until there is exhaustive proof that it can be ruled out. We must not miss the diseases that have the greatest effects on our patients. The consequences of missing adult-onset asthma are substantially less serious than those of misdiagnosing unstable atheromatous disease. Few people die of asthma, but unstable coronary plaques are the major cause of death in industrialized countries. It is not just prudent and economically sound but humane to rule out abruptly symptomatic coronary disease by virtually any means. The "expense of health care," to which Thibault dutifully alludes, is not just the cost in dollars but the human cost. The cardiac discussant deserves our applause and thanks from a properly served patient.

Portland, OR 97201-3141 2630 S.W. Commonwealth Ave. 
To the Editor: Why were pulmonary-function studies and a methacholine challenge not performed in the case presented by Thibault? These simple tests would have confirmed the diagnosis of asthma, easily obviating the need for a workup that probably cost well over $\$ 5,000$ without good evidence to pursue the course that was followed.

Wisconsin Rapids, WI 54494

Michael P. Mehr, M.D. Riverwood Clinic

To the Editor: The pulmonary consultant in this case should have heeded the diagnostic criteria enumerated in Guidelines for the Diagnosis and Management of Asthma, published by the National Heart, Lung, and Blood Institute. ${ }^{1}$ If pulmonaryfunction testing reveals air-flow obstruction that is reversible after bronchodilator therapy, asthma is the most likely diagnosis. A disease that affects 10 million Americans can be successfully diagnosed and managed, even if it is "only asthma."

Augusta, GA 30912

Howard J. Silk, M.D. Medical College of Georgia

1. National Asthma Education Program. Expert Panel report: guidelines for the diagnosis and management of asthma. Bethesda, Md.: Department of Health and Human Services, 1991. (NIH publication no. 91-3042.)

To the Editor: Careful attention to the history and physical examination, along with pertinent skin tests, would have demonstrated that the patient was allergic to molds (he wheezed while raking leaves, which are loaded with various molds) and to house dust or dust mites (he wheezed while cleaning a room). The emergency room physician is to be commended for making the correct diagnosis and prescribing the appropriate therapy - a bronchodilator and an antiinflammatorycorticosteroid inhaler. Precautions against dust in the bedroom would have been helpful as well.

The pulmonologist and cardiologist obviously viewed the case from the narrow perspectives of their own specialties. It is fortunate that the patient had a normal coronary angiogram, or he might have ended up being treated with bypass surgery. The pulmonologist could have contributed to the solution of this problem by performing a methacholine challenge. The use of a beta-blocker with minimal justification in a patient who had asthma not only was wrong but could have made the disease worse.

This case shows why the cost of medicine is so high. Thousands of dollars were spent on unnecessary tests and procedures.

Stamford, CT 06902

Leslie R. Goleman, M.D. Stamford Hospital

To the Editor: As a practitioner of the art of medicine, I am struck by how technology was used and abused in this case. The clinical diagnosis was apparently not acceptable to the patient and practitioner, so numerous tests were performed essentially to prove negative results.

I am curious about what drove this set of circumstances. Was it the threat of a lawsuit by the patient? Was it the threat of a lawsuit by the physician who was practicing defensive medicine? Was it the fee-for-service system that allowed tests to be performed unchecked, although there were few or no in- dications for them - particularly coronary angiography? Why did the patient allow these tests to be performed, given that he was free of symptoms?

Denver, CO 80220

Donald W. Aptekar, M.D. 4500 E. 9 th St.

\section{Dr. Thibault replies:}

To the Editor: Drs. Hammond, Mehr, Silk, and Aptekar all applaud the clinical judgment of the emergency room physician and decry the use of excessive tests and procedures. They suggest that a much simpler approach, such as the measurement of peak flow in the emergency room or a methacholine challenge (or both), would have been sufficient to attain a reasonable degree of diagnostic certainty. I agree that the methacholine challenge is a useful diagnostic test and that it is underused. The opinions of these correspondents reinforce the major point I intended to make.

Dr. Coleman suggests that allergy testing would have been helpful as part of the diagnostic workup for this patient. Allergy testing is low in cost and poses little risk. In fact, however, the diagnosis of asthma should have been made even if allergy tests had been negative.

Dr. Rudoff defends the pursuit of the diagnosis of atherosclerotic coronary disease because of the dire consequences of missing it. Clearly, this diagnosis must be pursued if the probability is high enough that the benefits of testing and treatment outweigh the risks. That balance between benefits and risks must be assessed for each patient on the basis of the history, physical findings, laboratory tests, clinical course, and response to therapy. In the patient I described, the evidence suggested that the probability of life-threatening proximal coronary artery disease was very low. The cost of attaining absolute diagnostic certainty in every instance is not just the economic cost to society but also the cost to the patient in terms of time, anxiety, and life-threatening complications. The most invasive approach is often not the most appropriate.

George E. Thibault, M.D. Veterans Affairs

West Roxbury, MA 02132 Medical Center

\section{AUTOLOGOUS CHONDROCYTE TRANSPLANTATION}

To the Editor: Brittberg et al. (Oct. 6 issue) ${ }^{1}$ are to be commended for conducting a study of 23 patients that not only involved the transfer of articular and nonarticular tissue into deep cartilage defects in the knee but also required two follow-up operations. In the second of those procedures, biopsy specimens extending to the subchondral bone were taken from the central part of the transplant.

In consideration of these factors, it is perhaps understandable that no control group was included in the study. Nevertheless, it would have been nice to know just how much benefit was derived from the substantial effort devoted to the harvesting, isolation, culture, and reinjection of the chondrocytes. Such information might have been obtained had, for example, some patients been randomly assigned to treatment with transplanted periosteum without cultured chondrocytes. 
Treatment of articular defects has been successful in preclinical studies that used periosteum without chondrocytes, ${ }^{2,3}$ that used periosteum with chondrocytes, ${ }^{4}$ and that excluded periosteum but used endogenous cells. ${ }^{5}$

Stephen B. Trippel, M.D.

Boston, MA 02114 Massachusetts General Hospital

1. Brittberg M, Lindahl A, Nilsson A, Ohlsson C, Isaksson O, Peterson L. Treatment of deep cartilage defects in the knee with autologous chondrocyte transplantation. N Engl J Med 1994;331:889-95.

2. O'Driscoll SW, Salter RB. The repair of major osteochondral defects in joint surfaces by neochondrogenesis with autogenous osteoperiosteal grafts stimulated by continuous passive motion: an experimental investigation in the rabbit. Clin Orthop 1986;208:131-40.

3. Rubak JM, Poussa M, Ritsila V. Chondrogenesis in repair of articular cartilage defects by free periosteal grafts in rabbits. Acta Orthop Scand 1982;53: 181-6.

4. Grande DA, Pitman MI, Peterson L, Menche D, Klein M. The repair of experimentally produced defects in rabbit articular cartilage by autologous chondrocyte transplantation. J Orthop Res 1989;7:208-18

5. Hunziker EB, Rosenberg LE. Induction of repair in partial thickness articular cartilage lesions by timed release of TGF $\beta$. In: Transactions of the 40th Annual Meeting of the Orthopaedic Research Society, New Orleans, February 21-24, 1994. Rosemont, Ill.: Orthopaedic Research Society, 1994:19:236. abstract.

To the Editor: The patients described by Brittberg et al. were evaluated with a four-grade system based on the presence or absence of pain, swelling, and locking. Were the qualitative terms for the four grades provided by clinicians or based on assessments by the patients? A patient's idea of what constitutes a good or excellent result may be completely different from that of a physician. For example, a patient who had "mild aching with strenuous activity but no swelling or locking" after surgery might have judged the result to be poor rather than good, which was the grade Brittberg et al. gave for this result. Evaluating a surgical procedure in an uncontrolled and unblinded fashion, with a scale developed and rated by clinicians, could have led to a biased assessment of success.

\section{Toronto, James G. Wright, M.D., M.P.H. ON M5G 1X8, Canada Hospital for Sick Children}

The authors reply:

To the Editor: The treatment of deep cartilage defects in the knee was based on a rabbit model in which a deep chondral lesion in the patella was covered with periosteum, and autologous chondrocytes were injected below it. A similar defect in the other knee, which was only covered with periosteum, served as a control. There was significantly better tissue repair at the sites seeded with chondrocytes than at the sites that were treated only with periosteum. ${ }^{1,2}$ In the experiments mentioned by Dr. Trippel, periosteum was used to treat osteochondral defects extending down to cancellous bone. ${ }^{3}$ The subchondral bone marrow cells, as well as cells in the cambium of the periosteum, have a chondrogenic potential that could contribute to tissue repair. In our rabbit experiments, there was no opening of the subchondral bone plate. The control knee had significantly less repair.

Knee symptoms in patients with single, isolated cartilage defects should be distinguished from symptoms in patients with osteoarthritis, which is characterized by widespread cartilage wear and joint dysfunction. There are no good evaluation systems for the first group of patients, but there are some for patients with osteoarthritis. In our pilot study, we used a simplified evaluation of common symptoms in patients with isolated cartilage defects (i.e., locking of the knee, localized pain, and swelling). The symptom that the patients could tolerate least was locking, followed by pain. Locking was the key element in judging the outcome of surgery. As long as the patient had no locking, he or she was satisfied with the results.

We agree with Dr. Wright that there is a risk of bias in the assessment of success in uncontrolled studies. We performed a pilot study of autologous chondrocyte transplantation in patients with isolated, symptomatic chondral lesions. Clinical studies with periosteal ${ }^{4}$ as well as perichondral ${ }^{5}$ grafting have also been uncontrolled. The next step is to determine the extent to which chondrocytes contribute to the repair of chondral lesions in the knee. A multicenter, randomized, controlled study is scheduled to start this year. Several different evaluation systems, with unbiased preoperative and postoperative assessments, will be used.

MAts BritTberG, M.D. Anders Lindahl, M.D., Ph.D. Lars Peterson, M.D., Ph.D.

S-413 45 Göteborg, Sweden University of Göteborg

1. Brittberg M, Lindahl A, Nilsson A, Peterson L, Isaksson O. Healing of injured rabbit articular cartilage after transplantation with autologously isolated and cultured chondrocytes. In: Abstracts of the Bat Sheva Seminars on Methods Used in Research on Cartilaginous Tissues, Tel Aviv, Israel, March 16-26, 1989. Nof Ginnosar, Israel: Bat Sheva, 1989:28-29. abstract.

2. Grande DA, Pitman MI, Peterson L, Menche D, Klein M. The repair of experimentally produced defects in rabbit articular cartilage by autologous chondrocyte transplantation. J Orthop Res 1989;7:208-18.

3. O'Driscoll SW, Salter RB. The repair of major osteochondral defects in joint surfaces by neochondrogenesis with autogenous osteoperiosteal grafts stimulated by continuous passive motion: an experimental investigation in the rabbit. Clin Orthop 1986;208:131-40.

4. Hoikka VEJ, Jaroma JH, Ritsilä VA. Reconstruction of the patellar articulation with periosteal grafts: 4-year follow-up of 13 cases. Acta Orthop Scand 1990;52:36-9.

5. Homminga GN, Bulstra SK, Bouwmeester PS, van der Linden AJ. Perichondral grafting for cartilage lesions of the knee. J Bone Joint Surg Br 1990;72: 1003-7.

\section{CASE 37-1994: JUVENILE CHRONIC MYELOGENOUS LEUKEMIA}

To the Editor: The case report in the October 13 issue ${ }^{1}$ describes a newborn boy with juvenile chronic myelogenous leukemia that was diagnosed on the basis of "an open-liver biopsy, which revealed an extensive . . . infiltrate composed of immature-appearing mononuclear cells . . . having reactivity for myeloperoxidase . . . and lysozyme." In our view, this diagnostic procedure was potentially dangerous for the patient and adds little information. In fact, the diagnosis could have been made by assessing the proliferation of the patient's granulocyte-macrophage progenitors in vitro.

In patients with juvenile chronic myelogenous leukemia, the peripheral-blood granulocyte-macrophage progenitors proliferate in vitro in the absence of exogenous granulocytemacrophage colony-stimulating factor (GM-CSF), even when the cells are plated at very low densities. ${ }^{2}$ In these patients, the growth is due to a striking hypersensitivity of granulocyte-macrophage colony-forming units (CFU-GM) to GMGSF alone ${ }^{3}$ and not to granulocyte colony-stimulating factor (G-CSF), as mistakenly stated in the Case Records. ${ }^{1}$

Spontaneous growth of CFU-GM depends on the presence 
of a small amount of GM-CSF produced by monocytes or macrophages, since the depletion of adherent cells abrogates this abnormal growth pattern. Thus, a simple clonogenic assay of the fraction of mononuclear cells derived from peripheral blood could have provided sufficient data, together with the clinical and laboratory findings, which included increased serum muramidase (lysozyme) levels, to establish the diagnosis of juvenile chronic myelogenous leukemia; this assay could also have been used to monitor remission.

Franco Locatelli, M.D. Patrizia Comoli, M.D. VitTorio Rosti, M.D.

27100 Pavia, Italy University of Pavia

1. Case Records of the Massachusetts General Hospital (Case 37-1994). N Engl J Med 1994;331:1005-12.

2. Estrov Z, Grunberger T, Chan HS, Freedman MH. Juvenile chronic myelogenous leukemia: characterization of the disease using cell cultures. Blood 1986;67:1382-7.

3. Emanuel PD, Bates LJ, Castleberry RP, Gualtieri RJ, Zuckerman KS. Selective hypersensitivity to granulocyte-macrophage colony-stimulating factor by juvenile chronic myeloid leukemia hematopoietic progenitors. Blood 1991; 77:925-9.

The discussants reply:

To the Editor: Locatelli et al. question the use of liver biopsy to make a diagnosis of juvenile chronic myelogenous leukemia in our patient. Since we are fully aware that such a diagnostic approach is unusual, we thank Dr. Locatelli and his colleagues for the opportunity to make clear that in this particular case, such a biopsy was both appropriate and necessary.

In the weeks preceding the liver biopsy, immunophenotyping of bone marrow aspirate as well as peripheral blood was nondiagnostic for any leukemic process, as were the findings on examination of two bone marrow aspirates and two bone marrow biopsy specimens. As noted in the case presentation, an aggressive workup continued. The liver biopsy was considered only when, over a period of a few days, serious respiratory distress developed as a result of rapidly progressing hepatosplenomegaly. A liver biopsy and a further bone marrow aspiration were performed at virtually the same time in order to establish the diagnosis of juvenile chronic myelogenous leukemia and exclude the possibility of primary liver disease. During this period the leukocyte count had risen from approximately 25,000 per cubic millimeter to 50,000 to 73,000 per cubic millimeter. When the biopsy indicated juvenile chronic myelogenous leukemia, systemic chemotherapy with daunorubicin and cytarabin was promptly instituted, with a rapid reduction in the burden of proliferating myeloid cells and alleviation of the respiratory compromise.

A clonogenic assay of mononuclear cells derived from peripheral blood can indeed confirm a diagnosis of juvenile chronic myelogenous leukemia. Such an assay, however, at best takes one to two weeks, especially if one seeks to measure sensitivity to GM-CSF in addition to spontaneous proliferation. The rapid progression of leukocytosis and hepatosplenomegaly in our patient rendered a clonogenic assay useless for diagnostic purposes.

Eric F. Grabowski, M.D., Sc.D. David H. EbB, M.D.

William S. Ferguson, M.D.

Boston, MA 02114 Massachusetts General Hospital

To the Editor: As pointed out by Locatelli et al., peripheralblood hematopoietic progenitors are hypersensitive to GMCSF and not to G-CSF, as erroneously reported in my case discussion. In studies by Gualtieri et al. ${ }^{1}$ and Emanuel et al., ${ }^{2}$ neutralizing antibodies to GM-GSF but not to G-CSF significantly reduced the spontaneous proliferation of hematopoietic progenitors obtained from patients with juvenile chronic myelogenous leukemia. These studies clearly indicate the part played by GM-CSF in this disorder. I thank Dr. Locatelli and his colleagues for affording me the opportunity to correct the record.

Stony Brook, NY 11794-8111

Robert I. PArker, M.D. State University of New York at Stony Brook

1. Emanuel PD, Bates LJ, Zhu SW, Castleberry RP, Gualtieri RJ, Zuckerman KS. The role of monocyte-derived hemopoietic growth factors in the regulation of myeloproliferation in juvenile chronic myelogenous leukemia. Exp Hematol 1991;19:1017-24.

2. Emanuel PD, Bates LJ, Castleberry RP, Gualtieri RJ, Zuckerman KS. Selective hypersensitivity to granulocyte-macrophage colony-stimulating factor by juvenile chronic myeloid leukemia hematopoietic progenitors. Blood 1991; 77:925-9.

\section{TRANS FATTY ACIDS IN EUROPEAN MARGARINES}

To the Editor: The content of trans fatty acids in our foods has been causing concern ${ }^{1}$ because of reported adverse effects on serum lipid levels ${ }^{2}$ and coronary heart disease. ${ }^{3}$ Even a typical Western diet can have enough of these trans isomers to elevate the risk of coronary heart disease considerably. ${ }^{4}$ Unfortunately, consumers themselves have only limited control over their intake of trans fatty acids, since despite progress in food labeling, the new regulations do not require information on trans fatty acids to be displayed on food packages.

Table 1. Composition of German, British, and American Margarines and Butter.

\begin{tabular}{|c|c|c|c|c|c|c|c|}
\hline \multirow[t]{2}{*}{ FATTY ACID } & $\begin{array}{l}\text { DiäTMAR- } \\
\text { GARINE } \\
\text { (GERMANY) }\end{array}$ & $\begin{array}{l}\text { REFORMHAUS- } \\
\text { MARGARINE } \\
\text { (GERMANY) }\end{array}$ & $\begin{array}{l}\text { FLORA } \\
\text { (U.K.) }\end{array}$ & $\begin{array}{c}\text { LAND O' } \\
\text { LAKES } \\
\text { COUNTRY } \\
\text { MORNING } \\
\text { BLEND } \\
\text { LIGHT (U.S.) }\end{array}$ & \multicolumn{3}{|c|}{ CORN-OIL MARGarine (U.S.) } \\
\hline & & & & & STICK & TUB & BUTTER \\
\hline & \multicolumn{7}{|c|}{ percentage of total fatty acids } \\
\hline $\begin{array}{l}\text { Hypercholesterolemic } \\
\text { saturated }\end{array}$ & 9.8 & 47.9 & 14.6 & 26.8 & 13.5 & 11.1 & 53.4 \\
\hline Lauric & 0.6 & 19.8 & 0.4 & 1.1 & 0.02 & 0.02 & 2.2 \\
\hline Myristic & 0.5 & 11.9 & 0.7 & 5.2 & 0.07 & 0.07 & 15.0 \\
\hline Palmitic & 8.7 & 16.2 & 13.5 & 20.5 & 13.4 & 11.0 & 36.2 \\
\hline Stearic & 7.4 & 4.6 & 4.1 & 8.4 & 4.3 & 4.0 & 10.1 \\
\hline Oleic & 22.7 & 19.0 & 25.4 & 21.7 & 10.7 & 21.5 & 18.8 \\
\hline Linoleic & 54.3 & 25.3 & 49.4 & 30.0 & 40.9 & 51.3 & 2.5 \\
\hline Trans & 1.2 & 1.4 & 0.5 & 2.0 & 18.6 & 9.0 & 3.4 \\
\hline
\end{tabular}


Margarine has been identified as one of the major sources of trans fatty acids. ${ }^{1}$ According to our analysis, the trans-fatty-acid content of margarines manufactured in the United States ranges widely from 0.1 to $0.9 \mathrm{~g}$ per teaspoon $(5 \mathrm{ml}$, or 2 to 18 percent of total fatty acids). ${ }^{4}$ Although American consumers who prefer margarine to butter do not have the ability to choose a margarine that has minimal or no trans-isomer content, European consumers do. In England, Flora margarine is promoted as having no trans fatty acids; we analyzed this product and confirmed that the trans-isomer content is negligible (Table 1). In Germany, products that are termed "diet" margarines (Diätmargarine) cannot contain partially hydrogenated fats or oils. To achieve the solid consistency of the diet margarines, manufacturers are permitted to blend the unmodified liquid oils with a small amount of "hardstock," which are naturally solid fats, or to hydrogenate 10 to 15 percent of the vegetable oil fully, thereby producing a fat richer in stearic acid, a saturated fatty acid that does not raise serum levels of low-density lipoprotein cholesterol. ${ }^{5}$ These products have a favorable composition of fatty acids: the trans-fatty-acid content is negligible, and the saturatedfatty-acid content is low (Table 1). The composition of diet margarines from the Netherlands ${ }^{6}$ is similar to that of the German ones.

In contrast, German products termed Reformhausmargarine (loosely translated as "natural" margarines) are prohibited from containing any oils that have been subjected to hydrogenation, partial or full. Unfortunately, the Reformhausmargarines derive their solid consistency from the addition of relatively large amounts of naturally hard palm-kernel oil, palm oil, and coconut oil, which enrich these not-so-healthy products with nearly 50 percent saturated fatty acids (Table 1). These prod- ucts are analogous to Land O' Lakes Country Morning Blend Light, a margarine recently introduced in the United States that is promoted as being free of trans fatty acids, in which butter is used to harden the product. Products such as Diätmargarine and Flora margarine demonstrate that a low amount of trans fatty acids need not be accompanied by an increase in saturated fatty acids that elevate serum cholesterol levels, as in the Reformhausmargarine or the American blend of butter and oil.

Margarines can be produced that appeal to the consumer and do not contain either trans fatty acids or high levels of saturated fatty acids. Although this has been done in Europe, American food manufacturers are still manipulating our foods in a way that current scientific research suggests may compromise health. Furthermore, the lack of information on trans fatty acids on food labels does not allow one to make an informed choice among available options.

Karin Michels, M.S., M.P.H. FRANK SACKS, M.D.

\section{Boston, MA $02115 \quad$ Harvard School of Public Health}

1. Willett WC, Ascherio A. Trans fatty acids: are the effects only marginal? Am J Public Health 1994;84:722-4.

2. Mensink RP, Katan MB. Effect of dietary trans fatty acids on high-density and low-density lipoprotein cholesterol levels in healthy subjects. N Engl J Med 1990;323:439-45.

3. Willett WC, Stampfer MJ, Manson JE, et al. Intake of trans fatty acids and risk of coronary heart disease among women. Lancet 1993;341:581-5.

4. Litin L, Sacks F. Trans-fatty-acid content of common foods. N Engl J Med 1993;329:1969-70.

5. Bonanome A, Grundy SM. Effect of dietary stearic acid on plasma cholesterol and lipoprotein levels. N Engl J Med 1988;318:1244-8.

6. Katan MB, Van de Bovenkamp P, Brussaard JH. Vetzuursamenstelling, transvetzuur- en cholesterolgehalte van margarines en andere eetbare vetten. Voeding (the Hague) 1984;45:127-33.

\section{BOOK REVIEWS}

\section{Vandals at The Gates of Medicine: Historic PERSPECTIVES ON THE BATTLE OVER HEALTH GARE REFORM}

By Miguel A. Faria, Jr. 403 pp. Macon, Ga., Hacienda, 1994. \$41.95. ISBN 0-9641077-0-8.

How is one to describe a book in which chapter 1 begins with the words "In the beginning . . ." and that then proceeds to discuss, in 32 chapters, the history of humanity and the development of medicine and medical ethics — up to, and including, the ill-fated Clinton health plan? The book has been written by a practicing neurosurgeon with wide-ranging interests. Its sweep through history is demonstrated by the 30 photographic plates of such mythological and historical figures as Osiris, Hippocrates, and Vesalius. The political leanings of the author, who escaped Cuba at the age of 13, are demonstrated by two other plates - one of him interviewing a wounded Salvadoran soldier, and another of his wife holding a SAM-7 missile launcher captured from a Nicaraguan plane transporting weapons to the Salvadoran guerrillas.

The book presents a conservative critique of modern efforts at reform of the health care system, along with a comprehensive historical review that Dr. Faria claims demonstrates the dangers of uncoupling private initiative and free markets from the provision of health care services. The principal target of the book is the Clinton health plan, but there are a host of other villains and evil forces in Faria's analysis, including lawyers, bureaucrats, practitioners of defensive medicine, the American Medical Association, laws governing medical and product liability, the media, liberalism (in general and in academia), egalitarianism, domestic socialism, and all the forces favoring the redistribution of income and property. The rhetoric is impassioned, in line with the sense of urgency in the title. Faria no doubt views the defeat of the Clinton plan in Congress with considerable satisfaction. Yet, as the list above reflects, he has a host of other matters of concern, apart from those relating to health care policy.

There is much to appreciate in this book. In relatively few pages, Faria has provided a compressed history of humankind, focusing principally but not exclusively on Western civilization. The book also gives a quick overview of the history of medicine and surgery. Those looking for an accessible yet wide-ranging introduction to these areas could do far worse.

Faria's chief complaint is that the government has increasingly intruded into the practice of medicine, by (among other things) its oversight over credentialing, reimbursement practices, the National Practitioner Data Bank, and monitoring of outcomes. In Faria's view, such matters would be better left to individual patients and to the medical profession. Certainly, government at all levels has steadily increased its involvement in medicine - particularly since the government has become a major source of funds for health care. One might certainly argue about the necessity or appropriateness of particular kinds of oversight, let alone a forced transformation of 